\title{
КОМПОНЕНТНЫЙ СОСТАВ ОРГАНИЧЕСКОГО ВЕЩЕСТВА САПРОПЕЛЕЙ МАЛЫХ ОЗЕР ЭСТОНИИ И НЕКОТОРЫЕ ПУТИ ИХ ИСПОЛЬЗОВАНИЯ
}

Проведенные нами исследования донных отложений малых озер Эстонии были направлены на выяснение условий залегания, химического состава и способов использования их в народном хозяйстве. С этой целью были отобраны пробы из 21 озера, расположенного в разных физико-географических условиях и характеризующегося разными морфометрическими параметрами. Большинство изученных озер (Кирикумяэ, Сааръярв, Кургъярв, Вайкъярв, Пангоди, Нейтсиярв, Ахвенъярв, Рябиярв и Юузаярв) находится на Хааньяской и Отепяской островных возвышенностях и имеет в основном, видимо, гляциокарстовое происхождение. Такое же происхождение имеют, по всей вероятности, и озера камовых полей Куртна (Яала Мустъярв) и Вийтна (Линаярв и Вохнья Кыверъярв). Озера Пяйдре (Сакалаская возвышенность), Кообассааре (Карулаская возвышенность) и Моосте (плато Юго-Восточной Эстонии) считаются эрозионными, а озера Саадъярвского друмлинного поля - Райгаствере, Элиствере, Просса и Каарепере Пиккъярв экзарационными (Kask, 1979). Озера Тыхела, Эрмисту, Юлемисте, Харку, Вескиярв и Кахала, расположенные на поднимающемся берегу Балтийского моря и отделившиеся от него на разных этапах развития этого моря, можно считать остаточными прибрежными озерами. Они часто занимают денудационные котловины, например, Юлемисте и Кахала.

Морфология озерных котловин сильно влияет на накопление и распространение в них донных отложений (Бружайте и др., 1975). Состав донных отложений озер, в свою очередь, во многом зависит от литологического состава окружающих отложений, гидрогеологических условий местности, биопродукции и др.

Для изучения были выбраны те озера, в которых в основном накапливались органогенные отложения - сапропели. Общее содержание органического вещества в них сильно варьирует (табл. 1). Чистые сапропели, содержащие органическое вещество более $50 \%$, встречаются в озерах Элиствере, Кирикумяэ, Кообассааре, Руйла, Пяйдре, Вайкъярв, Рябиярв, Сааръярв, Кургъярв, Вохнья Кыверъярв, Яала Мустъярв, Вийтна Линаярв, Қахала и Харку. Отложения озер Моосте, Пангоди, Нейтсиярв, Юузаярв и Ахвенъярв содержат сравнительно много терригенного и карбонатного компонента. Общее содержание органического вещества в отложениях озер является важным показателем, на основе которого можно делать предварительные заключения об использовании сапропелей. 
Содержание органического вещества (ОВ) в донных отложениях малых озер Эстонии

\begin{tabular}{|c|c|c|c|c|}
\hline \multirow{2}{*}{ Озеро } & \multirow{2}{*}{$\begin{array}{l}\text { Число } \\
\text { проб }\end{array}$} & Содержан & $\mathrm{OB}, \%$ & \multirow{2}{*}{$\begin{array}{l}\text { Средне- } \\
\text { арифме- } \\
\text { тическое }\end{array}$} \\
\hline & & $\begin{array}{c}\text { Минималь- } \\
\text { ное }\end{array}$ & $\begin{array}{l}\text { Макси- } \\
\text { мальное }\end{array}$ & \\
\hline
\end{tabular}

Кирикумяэ

Миссо Сааръярв

Кообассааре

Яала Мустъярв

Кахала

Вохнья Кыверъярв

Вийтна Линаярв

Вайкъярв

Руйла

Пяйдре

Элиствере

Рябиярв

Кургъярв

Ахвенъярв

Пангоди

Юузаярв

Вескиярв

Моосте

Нейтсиярв

$\begin{array}{rr}10 & 91 \\ 13 & 71 \\ 14 & 51 \\ 1 & \\ 13 & 75 \\ 14 & 41 \\ 25 & 42 \\ 19 & 34 \\ 11 & 40 \\ 17 & 28 \\ 10 & 34 \\ 3 & 15 \\ 6 & 14 \\ 20 & 18 \\ 36 & 32 \\ 21 & 19 \\ 10 & 12 \\ 28 & 10 \\ 27 & 7\end{array}$

95

87

87

83

80

80

80

64

64

57

56

56

56

48

46

46

34

33

31

Как и все природные вещества биологического происхождения, сапропели содержат разные группы веществ. При этом они являются не просто механическим накоплением планктонных форм, бентоса и растительных остатков, а продуктом протекающих в озерах сложных процессов. Накапливающийся на дне озер исходный органогенный материал сапропелей в основном под влиянием микро- и макроорганизмов подвергается глубоким преобразованиям (Казаков, 1950).

Групповой состав органической массы сапропелей определен на кафедре химии Латвийской сельскохозяйственной академии по усовершенствованной методике Е. И. Казакова (Шкеле, Удач, 1978б). Для этого были выбраны богатые органическим веществом отложения озер Кирикумяэ, Кообассааре, Яала Мустъярв, Вохнья Кыверъярв и Руйла, а также отложения Суурлахт. Раньше групповой состав сапропелей, по отобранным Р. Синисалу пробам, был определен из отложений озер Кахала, Юлемисте и Харку (Шкеле, Удач, 1978а), санирование которых является весьма актуальным.

Метод группового анализа основывается на разделении смеси органических веществ различными гидрофобными и физически действующими реагентами (раствор едкого натра, раствор серной кислоты). На основе аналитических данных в состав органической массы сапропеля входят различные углеводы, вещества протеиноподобного и гумусового характера и негидролизуемые вещества.

Би тумы представляют собой ту часть органической массы, в которой содержатся воски, твердые углеводороды, смолы, жиры, жирные кислоты и жидкие углеводороды (Казаков, 1953). Содержание битумов в наших озерах колеблется в широких пределах - от 6,2 до $15,1 \%$ (от сухого органического вещества; табл. 2). Полученные данные близки к данным по озерным отложениям Латвийской ССР (Бракш, 1971; Шкеле, Удач, 1978а). Высоким содержанием битумов характеризуются высокозольные сапропели оз. Харку. Так как воски и смолы могут быть применены в качестве технологического воска в разных отраслях хи- 
Групповой состав органической массы сапропелей некоторых малых озер Эстонии (\% на органическую массу)

\begin{tabular}{|c|c|c|c|c|c|c|c|}
\hline Озеро & $\begin{array}{c}\text { Золь- } \\
\text { ность, } \\
\%\end{array}$ & $\begin{array}{c}\text { Водо- } \\
\text { раство- } \\
\text { римые } \\
\text { веще- } \\
\text { ства }\end{array}$ & $\begin{array}{c}\text { Геми- } \\
\text { целлю- } \\
\text { лоза }\end{array}$ & $\begin{array}{c}\text { Биту- } \\
\text { мы }\end{array}$ & $\begin{array}{c}\text { Гуми- } \\
\text { новые } \\
\text { кис- } \\
\text { лоты }\end{array}$ & $\begin{array}{c}\text { Цел- } \\
\text { люлоза }\end{array}$ & $\begin{array}{c}\text { Негид- } \\
\text { роли- } \\
\text { зуемый } \\
\text { остаток }\end{array}$ \\
\hline Кирикумяэ & 4,7 & 2,8 & 0,2 & 8,2 & 19,6 & 2,3 & 22,2 \\
\hline Кообассааре & 15,6 & 2,7 & 0,2 & 8,4 & 29,3 & 1,5 & 50,3 \\
\hline Яала Мустьярв & 18,6 & 1,7 & 0,1 & 8,5 & 44,9 & 1,4 & 15,7 \\
\hline Вохнья Кыверъярв & 20,2 & 1,2 & 0,1 & 8,3 & 45,6 & 1,6 & 19,0 \\
\hline Руйла & 30,4 & 2,9 & 0,2 & 8,3 & 20,2 & 2,6 & 21,3 \\
\hline Кахала * & 41,7 & 5,3 & 13,4 & 9,5 & 13,0 & 0,5 & 19,6 \\
\hline Олемисте * & 48,9 & 3,2 & 9,1 & 9,5 & 16,1 & 1,1 & 16,0 \\
\hline Суурлахт & 68,8 & 2,4 & 0,2 & 6,2 & 17,4 & 1,1 & 25,4 \\
\hline Харку * & 91,0 & 8,4 & 14,0 & 15,1 & 19,9 & 1,0 & 32,4 \\
\hline
\end{tabular}

П ри мечание. Образцы приведены в порядке возрастающей зольности.

* - данные Шкеле, Удач, 1978а. Анализы провели В. А. Шкеле, Д. Э. Труксне, А. А. Войцеховска.

мической промышленности, а желтые пигменты представляют интерес в качестве витаминной добавки к корму, то, нам кажется, что сапропели с данной характеристикой следует изучить более подробно прежде всего определить содержание воска, твердых углеводородов, смолы, жира, жидких углеводородов и битумов $A$ и $C$.

Гуминовы е кислоты сапропелей отличаются от известных (Караваев и др., 1964) и точного названия пока не имеют (Вески, Фомина, 1978). Ниже мы называем их гуминовыми кислотами лишь условно.

Сапропели изученных озер содержат гуминовые кислоты от 20 (Кирикумяэ, Руйла) до 45-46\% (Яала Мустъярв, Вохнья Кыверъярв) на органическую массу. В относительно крупных озерах - Юлемисте, Кахала, Суурлахт - их содержание значительно меньше, нежели в малых. Так как котловины и водосборы изученных нами озер часто заболочены, то часть гуминовых кислот может быть привнесена в бассейн седиментации извне.

Практическое применение гуминовых кислот и их препаратов с каждым годом расширяется. Гуминовые препараты нашли применение в электрохимическом производстве, в нефтяной промышленности, при крашении, при изготовлении керамических изделий и в качестве сорбентов в атомной технике (Бракш, 1971; Лишван, Лопотко, 1974; Бракш и др., 1974). В настоящее время проводятся исследования по применению гуминовых веществ в качестве регуляторов роста растений и компонентов сложных комплексных удобрений.

Содержание углеводного комплекса (водорастворимые вещества, гемицеллюлоза, целлюлоза) в изученных нами сапропелях в несколько раз меньше соответствующих показателей для сапропелей других озер СССР (Казаков, 1950). Особенно низким, часто менее $1 \%$, является содержание гемицеллюлозы, в то время как в сапропелях озер Калининской, Ленинградской и Ивановской областей и Белорусской ССР содержание ее часто составляет $12-20 \%$, иногда даже больше (Казаков, 1950). Причины такого распределения отдельных компонентов органического вещества требуют дальнейшего изучения.

На основе проделанной работы можно высказать следующее. 
1. Характер донных отложений озер во многом зависит от литологического состава материнских пород на водосборах. Обогащенные органическим веществом сапропели наиболее часто встречаются в озерах, на водосборах которых распространяются песчаные отложения (камы, озы, флювиогляциальные дельты, зандры) и торфяники. В озерах холмисто-моренного ландшафта и друмлинных полей накапливались в основном карбонатные сапропели, местами со значительным содержанием терригенного материала.

2. Сапропелевые отложения изученных озер Эстонии отличаются низким содержанием водорастворимых и легкогидролизуемых веществ и повышенным содержанием негидролизуемого остатка по сравнению с отложениями сапропелей на соседних территориях. По всей вероятности, это обусловлено такими факторами, как продуктивность озер, климатическая зональность, характер распада исходного материала и др.

3. Прямой зависимости между зольностью и компонентным составом органического вещества нет (табл. 2). При увеличении содержания гуминовых кислот уменьшается содержание углеводного комплекса.

4. Учитывая полученные данные, сапропели озер Кирикумяэ, Кообассааре, Вохнья Кыверъярв и Руйла можно считать потенциальным сырьем для производства комплексных органо-минеральных удобрений, препаратов биологически активных веществ и аминокислот. Сапропели озер Юлемисте, Харку и Кахала можно рассматривать как потенциальное сырье для производства органо-минеральных удобрений.

Авторы признательны сотрудникам кафедры химии Латвийской сельскохозяйственной академии |Б. Вимба, В. Шкеле и Д. Труксне, которые на основе договора выполнили анализы группового состава.

\section{ЛИТЕРАТ У РА}

Бр а кш Н. А. Сапропелевые отложения и пути их использования. Рига, 1971.

Б ракш Н. А., Далб ин я М. Я., Дуб а в а Л. К. Основные направления технологического использования сапропелей. - Тез. докл. II Республ. конф.: «Проблемы использования сапропелей в народном хозяйстве». Минск, 1974, 59-60.

Бр у жайте Н. К., В асиляускен е М. Ф., Т амошайти с Ю. С. Краткая фнзико-географическая характеристика озер и их бассейнов. - В кн.: Накопление веществ в малых озерах Юго-Восточной Литвы. Вильнюс, 1975, 9-102.

В ески Р. Э., Фоми н а А. С. О термине «гуминовые кислоты». - Химия твердого топлива, $1978,3,74-79$.

Казаков Е. И. Генезис и химическая природа пресноводных сапропелей. - Тр. Ин-та горючих ископаемых АН СССР, 1950, 11, 253-265.

К азаков Е. И. Методика компонентного анализа органического вещества сапропелей. - В кн.: Методика изучения сапропелевых отложений. М., 1953, вып. I, $30-48$.

К а ра в а ев Н. М., В ене р Р. А., Королев а К. И. О составе и химической прнроде сапропелевых кислот. - Докл. АН СССР, 1964, 156, 4, 877-879.

Л и шв а н И. И., Л опо тко М. 3. Основные направления использования сапропелей в народном хозяйстве. - Тез. докл. II Республ. конф.: «Проблемы использования сапропелей в народном хозяйстве». Минск, 1974, 47-48.

Шкеле В., Удач Л. Исследование состава органических веществ сапропеля некоторых озер Эстонской ССР. - Тр. ЛСХА, 1978a, 141, 10-12.

Шкеле В., Удач Л. К методике компонентного группового анализа органических веществ сапропеля. - Тр. ЛСХА, 19786, 141, 7-9.

K a sk, I. Eesti järvede arvust ja järvenógude klassifikatsioonist. - Rmt.: Eesti NSV saarkõrgustike ja järvenôgude kujunemine. Tln., 1979, 88-103. 
Компонентный состав органического вещества...

11

Leili SAARSE, J. KASK

EESTI VAIKEJARVEDE SAPROPEELI RUHMALINE KOOSTIS JA SAPROPEELI KASUTAMISE VOIMALUSTEST

Artklis on esitatud sapropeeli orgaanilise ane ja sales leiduvate humiinhapete, süsivesikute ja bituumenite määramise tulemused ming tehtud järeldusi sapropeeli kasutamiseks.

Leili SAARSE, J. KASK

COMPOSITION OF THE ORGANIC MATTER IN SAPROPELS OF ESTONIAN SMALL LAKES AND SOME POSSIBILITIES OF THEIR APPLICATION

The paper deals with results of a group analysis of sapropels aimed at determining the content of organic matter. It has been elucidated that Estonian sapropels contain a rather low amount of water-soluble compounds and easily hydrolyzed compounds, and a high percentage of insoluble organic matter in comparison with the sapropels of neighbouring territories. The investigated sapropels might be used as fertilizers of soils and in the production of amino acids as well as biologically active substances. 